Article

\title{
The Digital Transformation of the Retail Electricity Market in Spain
}

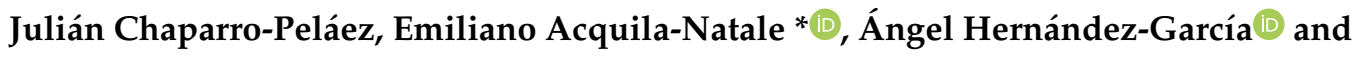 \\ Santiago Iglesias-Pradas
}

Departamento de Ingeniería de Organización, Administración de Empresas y Estadística, ETSI de Telecomunicación, Universidad Politécnica de Madrid, 28040 Madrid, Spain; julian.chaparro@upm.es (J.C.-P.); angel.hernandez@upm.es (Á.H.-G.); s.iglesias@upm.es (S.I.-P.)

* Correspondence: emiliano.acquila@upm.es; Tel.: (+34)-910-672-047

Received: 18 March 2020; Accepted: 15 April 2020; Published: 21 April 2020

check for updates

\begin{abstract}
The deregulation of the electricity markets in the European Union and the transformation caused by digital technologies and customer-centric strategies have altered the industry ecosystem, forcing companies to adapt to the new scenario. This research study aims to give a global overview of the digital transformation and channel integration of free-market electricity retailers in Spain from a consumer's perspective. The analysis includes all free-market electricity retailers that operate at the national scale, explores the level of digital transformation and channel integration of these companies based on a structured set of indicators, and measures them using the mystery shopper technique. The results show important differences between leading retailers and the rest of companies, evidence an important lag of the sector when compared to other retail markets and an overall lack of multichannel and omnichannel strategies, show a strong effort of retailers in online billing and self-service customer data management, and reveal shortcomings in the availability of communication channels with customers.
\end{abstract}

Keywords: electricity retailing; channel integration; digital transformation; end user

\section{Introduction}

The deregulation of the electricity market in the European Union has transformed the landscape of the sector [1]. In Spain, this deregulation has led to a slow transition from a State monopoly of all the activities-generation, transport, distribution, and commercialization-to a free market where the pressure of newly established companies forces companies to adapt their offer. This change comes hand in hand with the process of digital transformation across all industries [2] and the emergence of new business approaches and customer-centric models where the value for customers go beyond the mere provision of the service and instead lies on delivering complete and satisfactory customer experiences [3].

Such customer experiences now transcend the physical channel and extend to digital channels-web, mobile apps, social networks, etc., and push companies into integrating their product or service delivery across all available channels. Most companies are investing in adapting their commercialization strategies to the new digital era and, despite the abundance of scholarly research, there is still a need for the investigation of the opportunities and challenges emerging from digital transformation processes [4]. Furthermore, scholars and practitioners are just starting to investigate channel integration processes, omnichannel service delivery and simultaneous management of the available touchpoints and channels [5,6]. While the process of digitalization and channel integration has gained interest among academia and the industry in other sectors of retailing, e.g., goods such as clothing and apparel or consumer electronics, and services such as financial services [7-10], markets 
dealing with well-established commodities, e.g., telecommunication services, energy, have not received so much attention despite their particular characteristics; particularly, those related to the deregulation of markets that leave the door open to business innovation from new digital-born companies.

Compelled by the EU directives that deregulate national markets, the transition of the Spanish electricity market toward a free market has been steady but slow. Since 2003, all Spanish electricity consumers are eligible to choose their electricity supplier, but most are still supplied under regulated tariffs. At the end of 2013, more than half of the customers were supplied under the regulated mechanism [11]. This context sets up an interesting field for the analysis of how companies are implementing these adaptations and their impact on consumers' perceptions. Therefore, and adopting a consumer's view, this research aims to study the digital transformation of free-market Spanish national electricity retailers, i.e., companies that commercialize electricity throughout the whole national territory in the deregulated or free market, and explores their level of channel integration.

Public Administrations are devoting a vast amount of resources to foster the digital transformation of national companies to increase competitiveness and promote innovative business ecosystems [12,13]. In the case of electricity markets, the effort is geared toward the development of innovative customer relationships through digital channels to facilitate service hiring and management and improve the overall customer experience, as evidenced in preliminary industry reports [14]. That is, research on the aspects of the digital transformation related to omnichannel operation is still underdeveloped and companies are struggling to prioritize their digital services offering [15]. This study aims to shed light on this topic and to provide companies and policymakers-both national and international-with tools that facilitate assessment and benchmarking of the implementation of omnichannel strategies and customer-oriented digital services in the electricity retail market. From a theoretical perspective, the study develops a theory-based and empirically tested instrument that identifies indicators to measure the level of channel integration in services-based companies, adapting it to the characteristics of the electricity market and setting the basis for further replication and comparison of results.

In order to better guide the reader, it is necessary to provide a general overview of the different boundaries and factors influencing the configuration of the market, i.e., the regulatory framework and structure of the electricity market in Spain, and identify and differentiate the companies that take part in the deregulated or free electricity retail market. This description is followed by a general conceptual framework to study the digital transformation of companies and their level of channel integration based on individual indicators, the analysis of which may offer a general picture of the impact of digitalization in the industry from a consumers' view.

\section{The Spanish Electricity Market Landscape}

\subsection{Regulatory Framework and Market Agents}

Until 1997, the Spanish electricity market was strongly regulated: the State paid the costs of generation, transport and distribution, and set the market prices. The set of norms and rules applicable from 1988 to 1997 was known as the Stable Legal Framework (SLF). The SLF determined the electric rates that all operating companies could apply and sought to regulate the activity of all agents [16]. The regulatory framework also structured the market in four different activities: electricity generation, transport, distribution and commercialization.

While the Spanish Ministry of Industry and Energy calculated the standard costs associated with generation in an annual basis, the SLF effectively created a monopoly of electricity transportation, formalized in the Spanish Electric Network (SEN), a public company. Distribution was controlled by the medium- and low-voltage networks, owned and managed by private firms. Just like electricity generation, a fixed cost was established to guarantee the maintenance of the infrastructure. Electricity commercialization or retailing was governed by the idea of the Integral Rate, a tariff that was calculated by summing all the costs incurred in the generation, transport and distribution of electricity, and then 
dividing that number by the yearly estimated demand. During its period of validity, the Integral Rate had an annual growth of $2.8 \%$; considering a $4.8 \%$ annual inflation, the electricity bill fell by $2 \%$ [16].

The SLF was overruled by Law 54/1997 of the Electric Market [17], starting a transition towards a free market: the supply of electricity was no longer considered a public service and private companies began to take charge of some of the competences previously held by the State. The enforcement of Law 54/1997 did not cause a profound change in the agents of the electricity market but introduced a differentiation between regulated (transport and distribution) and partially regulated (generation and commercialization) activities [18]. Upon Law 54/1997, there are two types of electricity generating companies: 'special regime' companies, which generate electricity from renewable energy sources or co-generation not exceeding $50 \mathrm{MW}$, and the rest, or 'ordinary regime' companies; five companies generate most of the electric energy in Spain. The transport of electric energy is supported by the high-voltage network and the secondary transportation network, carried out by the SEN in exclusivity. The SEN matches supply and demand of electricity in the peninsular territory and the islands in real time. Distribution is carried out by private companies, and the State establishes the distribution costs that are included in the regulated section of end users' electricity bills. Five large companies cover $90 \%$ of the distribution, which is spread out over fixed areas, thus, consumers cannot choose their distribution company [19].

\subsection{Electricity Retailing}

Commercialization companies have access to transport or distribution networks and sell the electricity to end users. In Spain, approximately one third of the electricity is delivered to individuals [20], differentiating between free-market retailers and last-resource or reference retailers. The former may set their own prices, offer discounts and allow users to contract additional services, whereas the latter are designed by the State and are allowed to offer the Voluntary Price for End-Consumer, set by the State [17]. There are also differences between wholesale companies and retailers. The wholesale market (the Iberic Electricity Market, MIBEL) includes trading between generating and commercialization companies, and other qualified consumers. Retailers are the link between commercialization companies and SMEs (Small and Medium Enterprises) or residential end users [17]. Retailers must pay a price set by the State for the use of transportation and distribution networks. Law 24/2013 of the Electricity Market [21] differentiates between two types of retailers: non-regulated and reference commercialization companies. The former negotiate the price with the end user, whereas the latter may sell the electricity at a price set by the State, applicable to contracts under $10 \mathrm{~kW}$.

The relation between companies and end users entails three different processes: offer, billing and after-sales service. Retailers may offer their electricity plans through different channels, which are then contracted by the user. The billing of the service occurs on a monthly or bimonthly basis based on the power and plan contracted by users and their electricity consumption, which is generally measured by the company. In Spain, five companies represent around $90 \%$ of the electricity retail market: Endesa, Iberdrola, Naturgy, EDP España, and Viesgo, with a total revenue of approximately 41 billion euro in 2018 [22]. This market concentration has raised critique about the existence of large corporate groups that control most of the market, hindering actual competence. Nonetheless, after the establishing of the free market, and according to the market supervising authority, there are currently 369 free-market electricity retailers [23].

The residential or end-user segment has traditionally had high entry barriers for new companies other than the big five companies above. There are currently more than 28 million consumers in the retail market-26 million excluding SMEs - and $61 \%$ of them are supplied by a free-market retailer (up from 57\% in 2017). Most recent reports [24] indicate that the penetration of new companies has grown from $2 \%$ to $8 \%$ in the 2018-2019 period, with a total share of $30 \%$ of the supplied energy in 2018 . Regarding consumers, it is worth noting that the sector has a switching rate of $8 \%$, and that in 2018 the number of customers that switched from a free-market company to a reference retailer almost doubled, which indicates the difficulty that free-market retailers are having retaining their customers-the 
loyalty rate fell from $50 \%$ to $42 \%$ in 2018. In addition, electricity services in Spain have the lower satisfaction rates across all industries [25], with one out of five consumers stating that they are not satisfied with the service and more than 1 million complaints filed in 2018 (3.6 for each 100 consumers). These figures evidence the uncertainty and instability of the market, but also the opportunities arising from a correct implementation of digital services to support customer-centric approaches.

\section{The Digital Transformation of Electricity Retailers: A Consumers' View}

\subsection{Digital Transformation}

The process of digital transformation is a consequence of the incorporation of information technologies to most of the internal and external business operations. The digital transformation facilitates effective engagement of consumers throughout the whole customer lifetime [4]. The rapid development of information technologies, increased competition and changes in business orientation toward customer-centric approaches have accelerated this process across all sectors [26]. Smartphones, social networks, big data, cloud computing, data analytics, artificial intelligence, and device interconnection - the so-called internet of things-are at the forefront of this transformation, serving as the cornerstone of competitive advantage generation in the digital era. The digitalization process is independent of company size, business model—physical, digital, or multichannel—, or economic sector $[27,28]$. The main challenge that companies face is the optimal combination of physical and digital resources to create value for their customers [27]. Companies that succeed in managing effectively this process may achieve an advancing competitive edge by improving customer experience, optimizing commercial and logistics processes and being able to generate new business models [26].

Impact of the Digital Transformation in the Spanish Electricity Market

As detailed in Section 2, companies in the electricity retail market have been forced to adapt and modify their service offer and delivery as a result of the deregulation of the market. On the one hand, by incorporating new ways to generate and consume energy-e.g., self-generation or self-consumption-; on the other hand, by automating and integrating communication services and channels to interact with customers, as well as providing additional functionalities and services related to the monitoring, billing and managing of energy consumption [28,29]. More particularly, and regarding the digitalization of commercialization activities and improvement of customer experience, companies feel the need to provide digital means to manage service contracting, payments and online billing [30]. Current indicators of digital maturity evidence the lack of development of the energy sector in Spain; for example, only $25 \%$ of the companies have two-digit shares of online sales, $40 \%$ have customer web portals and $30 \%$ use customer data for digital management purposes [12].

Considering the objective of this study and building from prior literature, this research considers a series of indicators to measure the degree of digital transformation among free-market Spanish national electricity retailers, from a customer perspective, in other words, the study of the application of digital technologies seeking to optimize internal processes is considered out of the scope of this research. Consistent with the literature above, this study assesses the degree of implementation of consumption monitoring (i.e., remote digital metering), consumption and plan assessment (e.g., personalized recommendation of service plans), digital billing, online billing history, complete online service hiring, self-service digital customer data management (e.g., online plan changes or hiring of new services managed by users) and availability of digital customer services via instant messaging, e-mail, online chat, social networks and mobile apps.

\subsection{Channel Integration}

Business strategies currently focus on increasing the integration of the different operations and activities of the company, with a clear attention to putting the customer at the center of such activities [31-33]. Because of the changes caused by the digital transformation of organizations, 
companies are not only shifting their attention to channel integration, but also work in delivering unique customer experiences to improve overall customer satisfaction and retention. Therefore, channel integration is turning into the cornerstone upon which companies combine the objective, design and implementation of sales channels to offer satisfactory and superior customer experiences [34,35].

In this new market context, companies that aspire to deploy a joint and integrated channel strategy may have different levels of channel integration, e.g., single-channel, multi-channel, cross-channel, omnichannel [36-38], or even integrate different elements of their channel offering at dissimilar speeds. There also seems to be a consensus among researchers and practitioners in that omnichannel operation is the future of retailing because it is the only way companies may provide consumers with seamless, coherent and satisfactory shopping experiences [39-42] that are more appealing to customers who perceive the different channels as alternative ways to access the same information and products $[40,43]$ and who, driven by the advantages of integrated models, are more loyal and profitable $[35,37,44,45]$. Aware of this, large companies are starting to adopt measures and strategies leading to omnichannel operation. By 2015, only approximately one third of European and American companies had incorporated basic elements of channel integration, with forecasts predicting a progressive increase in the next years [46-48]. Current figures of channel integration have likely increased in the past years, even though there is still a long way to run to achieve complete omnichannel operation [15]. It is also widely acknowledged that higher levels of integration may improve overall customer experience, but companies generally lack appropriate instruments to measure the degree of channel integration or even understanding about which elements to consider for such measure.

So far, the only effort to quantify channel integration levels may be found mostly in industry reports (e.g., [49-52]). These reports rarely detail the full set of indicators used in their assessment and tend to define arbitrary weights for the indicators. The approaches to the study and characterization of channel integration levels used by scholarly research, on the other hand, tend to focus on specific aspects of integration strategies, but without a clear and structured framework of study (e.g., [33,41,42,53,54]). The only research that has addressed this topic with an integral view is [15]. Focusing on the clothing and apparel sector, the authors propose a model that allows measuring, in a structured way, the degree of channel integration of different companies throughout the whole shopping process. The proposed model, which serves as the basis for this study, defines a set of indicators to measure the level of channel integration in six different areas of the company: customer touchpoints, channel consistency, integrated promotion, integrated access to information, fulfillment, and customer service.

Customer touchpoints capture the idea of the different moments when companies and consumers have a bidirectional interaction $[36,55,56]$, As such, they are implemented over different channels along the shopping process. Companies may increase their touchpoints by operating in different channels, which become the more visible representation of omnichannel retailing [50,53]. In this study, the assessment of customer touchpoints covers the three most relevant and prominent channels at the present time: physical store, online store/portal and phone. Channel consistency is related to whether companies provide customers with a cohesive view of their brand image, the information available and their product offering, prices, and promotions across the different channels $[41,57,58]$. Omnichannel retailers should seek to have a coherent image, display homogeneous information about products and offer the same products at similar or same prices in the different channels they operate $[54,58,59]$. Integrated promotion involves cross-promotion from one channel to other channels, allowing and even encouraging consumers to use any channel at their convenience $[41,54,58,59]$. Integrated promotion takes full advantage of the omnichannel store as a platform to entice consumers into using alternative channels $[43,60,61]$, increase the reach of promotional actions and campaigns and reduce consumers' perception of risk in channels with which they have no previous experience $[62,63]$. Integrated access to information allows consumers to access data about one channel from the rest of channels [35,39,59,64]. If channel consistency measures the coherence of the information offered in each channel, e.g., same products, prices, etc., integrated access to information involves making it possible for customers to check information specific to one channel from any other channel. Integrated information also 
means that any information about customers and their relationship with the company is consistent, independently of the channel used by the customer. Integrated fulfillment involves the synchronization of all order management and distribution operations among the available channels $[43,65]$. This idea materializes in the different options provided by companies regarding place and time of product payment, delivery, pick-up or return $[39,59,65]$. The sixth and final area includes all aspects concerning the integration of customer care services, which means that consumers may access these services-not only after their purchase, but at any given moment-using the channel of their preference $[39,43]$ and concerning issues pertaining to any available channel [66].

In [15], the authors warn that the underlying principles of the definition of adequate indicators of channel integration may be of application in mostly every sector, but also that it is very likely that it is necessary to make adjustments and adaptations to the particular characteristics of other sectors before applying the instrument. The following subsection discusses the application and respecification of the channel integration framework in [15] to the electricity retail market.

\section{Measuring Channel Integration in the Electricity Retail Market}

The respecification of the channel integration measurement model to the electricity retail market requires some previous considerations. First, integrated fulfillment in [15] includes the payment, delivery, pick-up and return of the product, which makes sense in the case of goods but is not applicable to the delivery of intangible services such as electricity, and is therefore removed from the instrument.

Second, in the case of electricity retailers the use of mobile apps to interact with the company and access the different services is only possible once the service is hired, that is, unlike mobile apps developed by retailers in other sectors that allow users to navigate the catalog and purchase a product, there is no option to download and use the mobile app for non-customers of electricity retailing companies. However, because the availability of the mobile app is a signal of digital transformation of the company, this touchpoint will be included as an indicator of digital transformation.

Third, regarding integrated access to information, the indicators that are specific to physical goods-online-offline stock, product scan, transferability of the shopping cart, and integrated loyalty programs-are not considered in this study. The original 'transferability of the shopping cart' and 'order tracking' have been merged into a single indicator, 'integrated tracking of hired services', which refers to the availability of mechanisms to switch channels and resume the hiring process at the same point it was left, in any given moment. Two additional items are retained-interactive kiosks and free Wi-Fi in physical stores. Finally, 'integrated shopping history' is not considered applicable to the context of the study but may be adapted in the form of 'online billing history' as an indicator of digital transformation.

Fourth, one limitation of [15], acknowledged by the authors, is the omission of emerging digital channels, such as social networks, as sales channels. While this omission is still true in the case of the electricity retail market, the use of social networks and instant messaging platforms, e.g., WhatsApp and Telegram, to provide consumers with additional touchpoints for customer service implies additional channels that need to be managed and integrated. Therefore, this study will cover contact phone, e-mail, online chat, instant messaging platforms and social networking sites as indicators of integrated customer service. In line with the definition of integrated customer service given in the previous section, it is worth noting that the availability of these channels by themselves may be indicative of higher levels of digital transformation, but the study will only consider that they are integrated when they allow users to address issues that may occur in any available channel.

Finally, and consistent with the original proposal of [15], all the indicators of channel consistency-uniform brand, synchronized prices and promotions and synchronized products (in the case of electricity retailers, products refer to the different plans offered)-and integrated promotion (on-off and off-on) are considered applicable to the electricity retail market and are therefore retained in this study. 


\section{Materials and Methods}

\subsection{Research Method}

The analysis takes the consumer's view of the firm; that is, the analysis of the different indicators of digital transformation, as well as those referring to channel integration, only take into account the perception of consumers about the different processes and services offered by the companies. Therefore, aspects of the digital transformation related to internal processes (e.g., cloud architectures, process optimization facilitated by big data analysis or application of artificial intelligence) are out of the scope of the study. The research method for data collection used in this study is the 'mystery shopper' technique, a participant observation method, whereby researchers act as customers or potential customers to monitor the processes and procedures used in the delivery of a service to analyze the customer experience process [67].

Following the mystery shopper technique, all the information related to digitalization and channel integration has been collected from information about the companies that is publicly available in their website. In cases where no information was provided about some indicator, the research team contacted the companies' customer service by phone, e-mail, chat and instant messaging apps, when available, to check whether the different services were offered by the company. From Section 3, data about the following indicators have been collected:

- Channel integration I (3): customer touchpoints, or presence in different channels for end-user services (3): telephone, physical channel, online channel.

- Digital transformation (11): consumption monitoring, consumption and plan assessment, digital billing, online billing history, complete online service hiring, digital customer data management, availability of digital customer services via: (a) instant messaging; (b) e-mail; (c) online chat; (d) social networks; and (e) mobile app.

- Channel integration II (13): channel consistency (3): uniform brand, synchronized products, synchronized prices and promotions; integrated promotions (2): online to offline, offline to online; integrated access to information (3): free $\mathrm{WiFi}$, interactive kiosks, integrated tracking of hired services; integration of customer care services (5): contact phone, e-mail, instant messaging, online chat and social media.

In line with [15], the different indicators do not have any associated weight, i.e., all indicators are considered of equal importance, their values will be 0 or 1 , depending on whether the indicator is absent or present, respectively. There are some exceptions that allow for half scores (0.5) and these exceptions are explained in the analysis.

\subsection{Sample Selection}

Considering the large number of electricity retailing companies present in Spain, the following steps have been followed for sample selection:

- A list of all (564) electricity retailers in Spain has been collected from the official information provided by the CNMC, the Spanish National Commission for Markets and Competence. From this list, currently deregistered (195) companies have been removed.

- From the remaining 369 companies, only those that are classified as operating at a national level (73) have been chosen.

- A second list of companies was elaborated with information from the eInforma (https: //ranking-empresas.eleconomista.es) database (a complete database with financial information of all Spanish companies), where the selection criteria were companies considered "large" or "corporate"-revenue higher than 3 million euro-and under the code "3514. Commercialization of electric energy". The total number of companies from this list is 99.

- Only matching companies (61) across both lists are retained and inspected one by one. Because this study focuses on electricity retailers that offer their services to end consumers in the free 
market across the whole country, it has been necessary to remove the four reference retailers, as well as companies that only offer service to businesses and those that operate only in a specific area in Spain. The final list includes 19 companies.

\subsection{Data Analysis and Results}

The analysis of the collected data is structured as follows: first, we analyze the channel offering of our sample of free-market Spanish national electricity retailers; second, we discuss the results of the assessment of their digital transformation globally and on a per indicator basis; third, we examine their level of channel integration in detail.

\subsubsection{Customer Touchpoints (Channel Offering)}

From the data collected, only $32 \%$ of the companies under analysis have a multichannel strategy, that is, they offer their services through physical and digital channels jointly, $21 \%$ of the companies only offer their services through physical offices and $47 \%$ only allow online service.

Regarding Figure 1, it is important to note that, even though all the companies are authorized to offer their services at a national level, nearly a third of them do not have local offices in all the territory. For example, Atlas Energía Comercial only has offices in Barcelona, Lleida and Seville, and Evergreen Eléctrica only has a local office in Málaga. Regarding online presence, one of the companies-Sunair One Energy - does not facilitate a complete automated online process to hire their services at this moment, and instead they use e-mail as the only way to contract a plan. Because it cannot be established that the channel has been fully developed, a score of 0.5 out of 1 has been assigned in the respective channel indicator to these companies. It is also worth noting that all the companies allow consumers to hire and manage their services via telephone or e-mail, facilitating the remote completion and management of the process without paper document exchanges. However, for the purposes of this study, this situation is not analyzed because the process cannot be considered as automated or fully digitized.

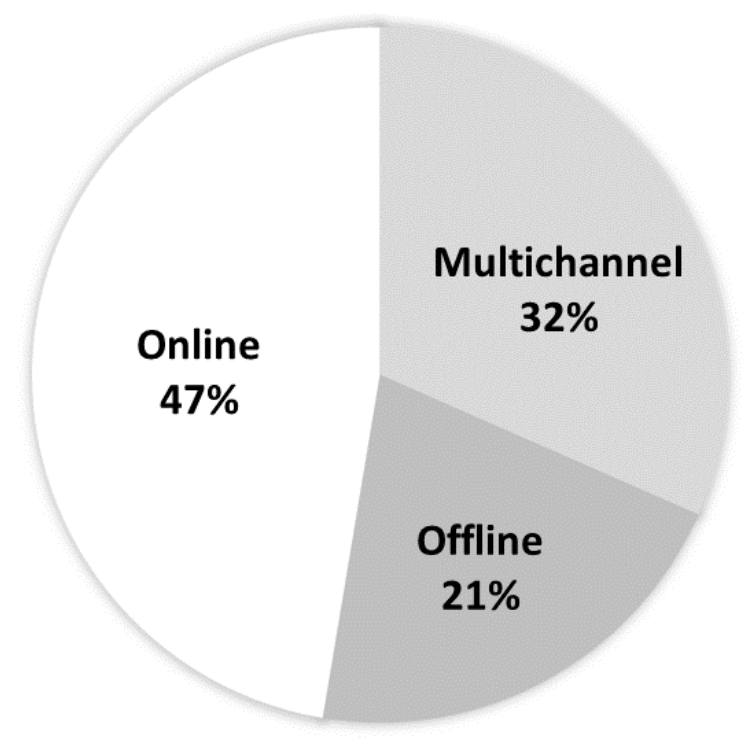

Figure 1. Channel offering by free-market Spanish national electricity retailers.

\subsubsection{Digital Transformation: Global Overview and Indicators}

Around $90 \%$ of the companies have incorporated at least half of the digital services under analysis (Figure 2). The results evidence the effort of the companies to incorporate digital services in the last years. 


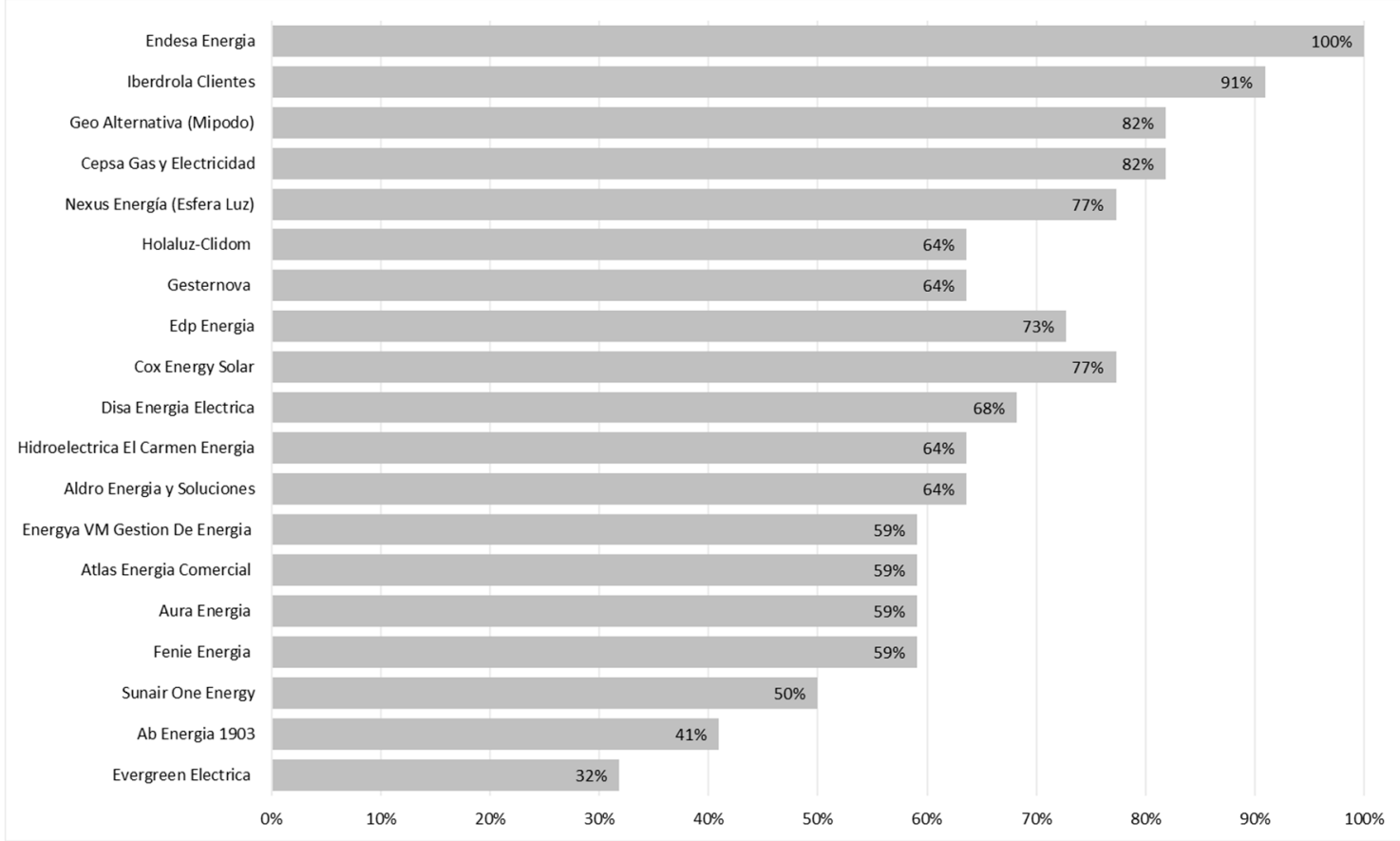

Figure 2. Digitalization of services among free-market Spanish national electricity retailers.

Figure 3 details the degree of implementation of digital transformation services across free-market Spanish national electricity retailers. An analysis and discussion of the results of the analysis is detailed next.

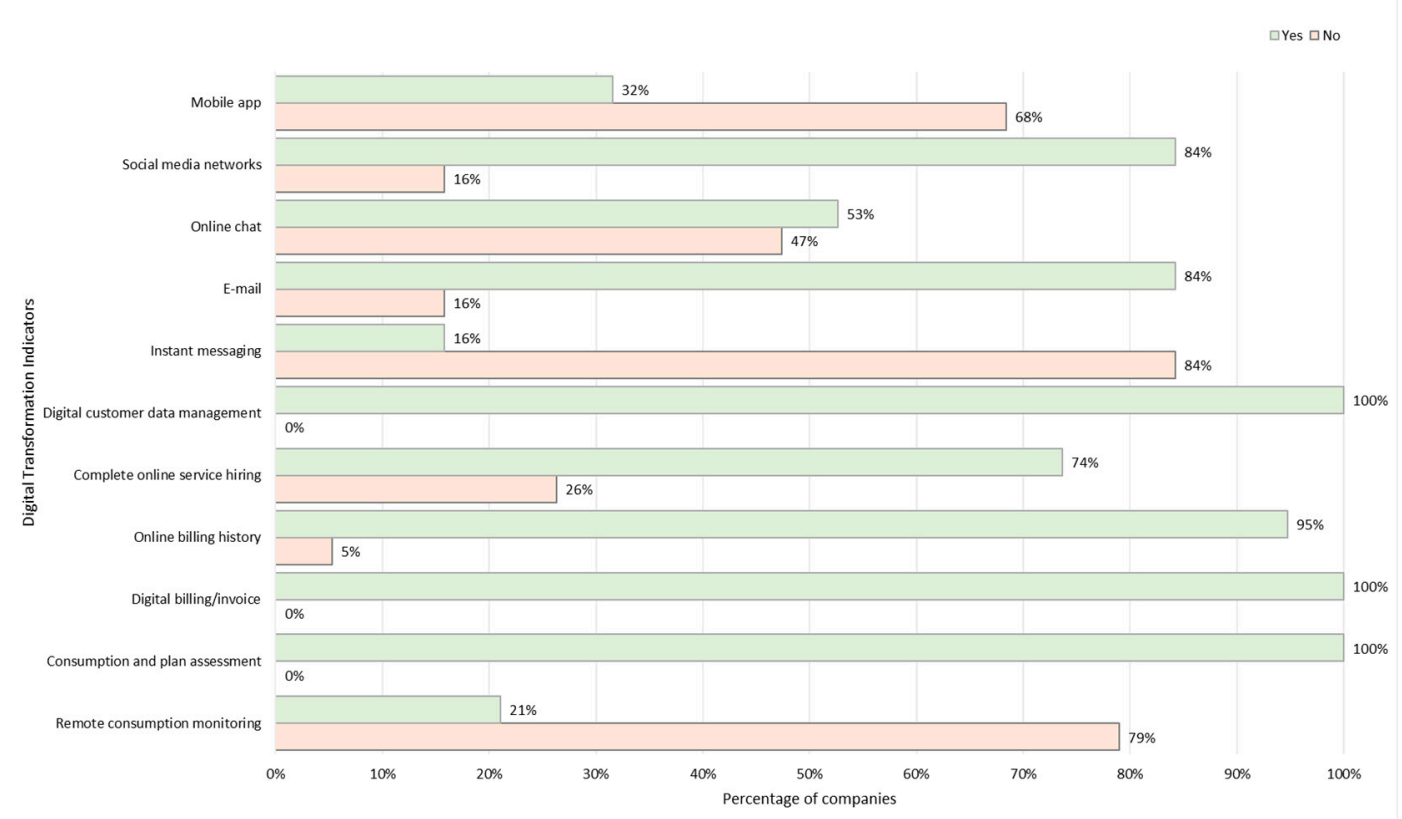

Figure 3. Indicators of digital transformation across free-market Spanish national electricity retailers.

Approximately the top half of Figure 3 refer to the communication channels that electricity retailing companies make available to users for customer service purposes, in addition to the traditional contact phone. The results show a clear unbalance in the implementation of these services. Thus, whereas $84 \%$ of the companies have a contact e-mail and social media account (most commonly, Facebook 
and Twitter, and also Instagram in some cases), around half of them (53\%) offer online chat and only a minority facilitate contact using instant messaging apps, primarily via WhatsApp. Regarding the latter two, it is interesting to observe that companies try to offer at least one of the two-around $60 \%$ of the companies offer at least one. The results of the analysis show a limited availability of mobile apps (32\% of the companies offer one) and a big difference in the use of mobile apps when compared to other retailing sectors: in the electricity retail market, mobile apps are designed primarily to facilitate interaction with customers and management of customer services, that is, they have a focus on the post-purchase stage, whereas mobile apps in other sectors (e.g., clothing and apparel, groceries, banking, etc.) use mobile apps as a sales channel throughout the whole shopping process, offering services to both customers and non-customers. Instead, electricity retailers tend to replace, or complement if they do offer them, the use of mobile apps for web portals to facilitate the management of hired services.

Regarding online hiring, billing and management of hired services, the analysis evidences the effort made by electricity retailers to make these services available to users. All the companies offer online billing and the large majority of them facilitate online billing history in their website, the only exception being Evergreen Eléctrica, which is currently implementing a new web portal for customers. In addition, $74 \%$ of them allow to complete the contracting process fully online. Concerning self-service customer data management, customers of half of the companies may perform plan changes online (e.g., maximum power consumption, changes to the contract holder, bank account data, etc.) by accessing their online customer profile. For the other half, these changes may only be managed via telephone or e-mail, in these cases, a score of 0.5 points has been assigned to the company.

The last two indicators of digital transformation that are particularly specific to the electricity sector are consumption monitoring and consumption and plan assessment. Regarding the former, only $21 \%$ of the companies offer real-time information of electricity consumption using the customer web portal. It is worth noting that the information about hourly or daily consumption is actually collected by electricity distribution companies, not by retailers, which shows the effort made by some retailers to integrate this information in their own web portals, especially when the companies are not affiliated to any of the distribution companies. As regards consumption and plan assessment, all the companies offer an analysis of the best plan for prospect customers based on the study and analysis of previous bills, facilitating the interaction and offering of their services via e-mail.

\subsubsection{Channel Integration: Global Overview}

Unlike the case of the digital transformation process, the results of the analysis show a limited or inexistent development of channel integration across free-market Spanish national electricity retailers (Figure 4). The average level of integration is $20 \%$ and it is mostly explained by the prevalence of single-channel strategies in 13 out of the 19 companies under analysis. Only four companies achieve $50 \%$ or higher channel integration levels: Iberdrola Clientes (85\%), Endesa Energía (77\%), EDP Energía (69\%), and Disa Energía Eléctrica (54\%). 


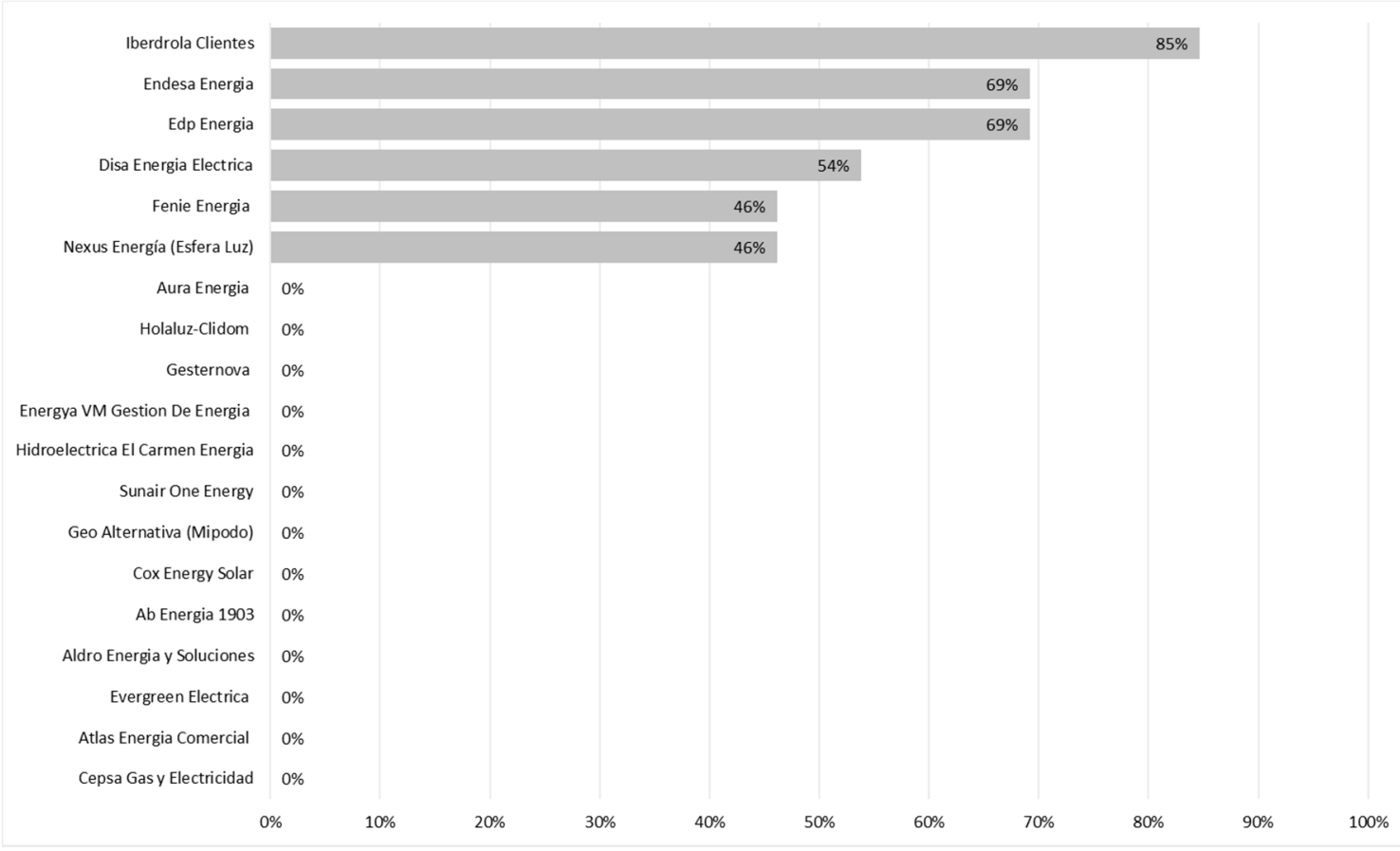

Figure 4. Global level of channel integration across free-market Spanish national electricity retailers.

In order to provide a more detailed discussion of each of the indicators (Figure 5), the following subsections analyze each group of indicators. It is important to note that only the six companies that offer both online and offline customer touchpoints have been included in the analysis.

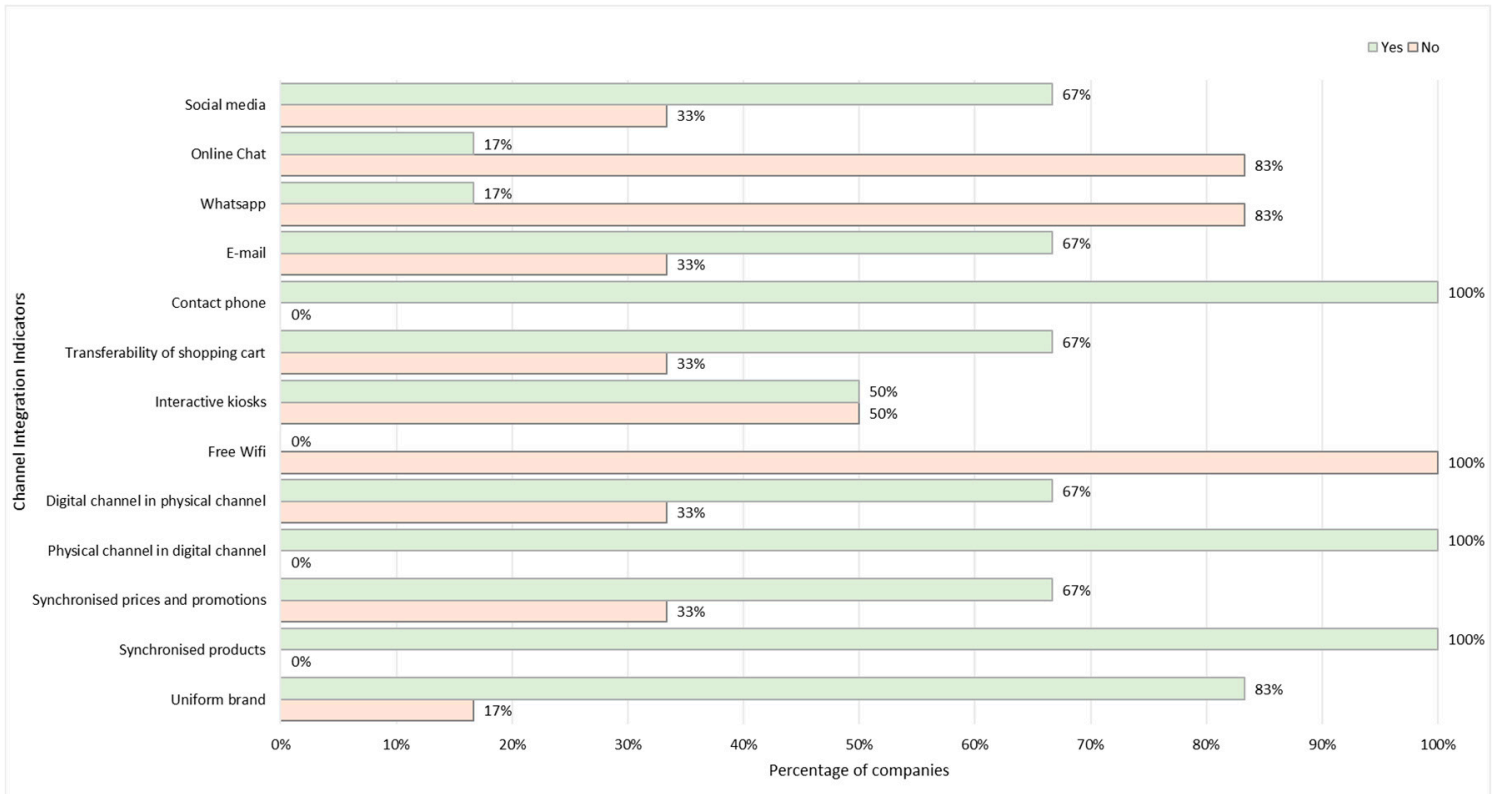

Figure 5. Indicators of channel integration across free-market Spanish national electricity retailers.

Regarding channel consistency, most companies have a consistent and uniform brand and synchronized products across channels, $83 \%$ and $100 \%$, respectively. In the case of brand image, two of the companies, Endesa and Fenie, work with affiliated companies that do not commercialize their products in exclusivity nor use brand identification elements in order to have physical offices in the majority of the national territory. Price synchronization occurs in nearly $67 \%$ of the companies, they 
offer the same plans and rates across both channels, Endesa and Esfera Luz have different prices that seem to incentivize the use of the digital channel.

Online to offline promotion is made by all companies: every company provides the location, contact phone and opening hours of their physical offices and associated service points. However, only $70 \%$ of the companies promote their digital channels in physical offices and stores and the same consideration about Endesa and Fenie applies in this case.

The offer of free WiFi and availability of interactive kiosks in physical offices is rare or inexistent. The cause of the absence of these services may lie in that sales associates generally have access to personal computers to handle all the information and paperwork involved in the hiring and management of the services. Interestingly, half of the companies provide users with tools to facilitate self-management through interactive kiosks. Finally, $67 \%$ of the companies allow users to initiate the contracting process in one channel and complete it in another one; companies also put the different channels at the disposal of future customers to answer questions or resolve issues throughout the whole contracting process in a way that it is not necessary to start over the process again when switching channels.

Lastly, and regarding integrated customer care services, all customer issues, inquiries and complaints may be handled via telephone, whereas e-mail and social networks $(67 \%)$ are available in all companies as integrated services but the degree of implementation of instant messaging applications and online chat is not common (17\%).

Following this overview of the Spanish end-user electricity retail market, the study seeks to explore trends on strategies in the implementation of customer-oriented digital transformation and channel integration among the companies included in the sample. To this end, a cluster analysis has been performed, using two different methods: (1) a two-step cluster analysis to select the number of clusters using the Bayesian information criterion (BIC) to determine the most adequate number of clusters, followed by a k-means cluster analysis, in SPSS 26; and (2) a Model-based clustering based on parameterized finite Gaussian mixture models using the mclust package in $\mathrm{R}$.

Both analyses return the same two clusters (see Appendix A for further details about the companies in each cluster), except for one company (Cox Energía Solar), assigned to different clusters depending on the type of cluster analysis. Cluster 1 (9 companies) groups the digital transformation and channel integration leaders and Cluster 2 ( 9 companies) is comprised of companies lagging in the digitalization of customer-oriented services. Cluster 1 includes the top 5 companies in terms of revenue, the top 5 according to the digital transformation index defined in this study - the top 9 excluding Fenie Energía-, and all omnichannel retailers, again excluding Fenie Energía, along with one of the largest first-comers - Holaluz (Clidom) was the first virtual retailer- and one new company, Geo Alternativa (Mipodo). The latter two commercialize electricity generated from renewable sources only. The results evidence the slow digital transformation of the electricity retail market and identifies a gap between the leaders and the rest of national free-market retailers. Even though there is no significant difference in offline presence between the two clusters, all the companies in Cluster 1 have online customer touchpoints, compared to only half of the companies in Cluster 2. In addition, only companies in Cluster 1 are currently offering remote consumption monitoring and complete online services contracting. All the companies in Cluster 1 have online chat, for only one of the companies in Cluster 2 , and the only three companies without social media presence belong to Cluster 2 - two companies in Cluster 1 have yet to integrate social media as part of their customer care services.

\section{Discussion}

\subsection{Main Findings}

Though scholarly interest in how companies are facing the digital transformation and channel integration toward omnichannel retailing has increased in recent years, the focus has generally shifted to retailing of goods. By focusing on commodities — in this case, electricity retailing一, this study 
offers a novel addition to the literature. The sample used in this study includes nineteen of the largest electricity retailers in Spain, because smaller retailers face additional barriers that hinder their digitalization, such as limited capital availability to invest and uncertainty about the net benefits of digitalization, and put them behind in the adoption of digital tools and processes [68] The sample in this study is very likely to represent the current higher levels of digital transformation and channel integration. The analysis evidences a remarkable gap between the implementation of customer-oriented digital services in the sector, especially when compared to more developed sectors (e.g., clothing and apparel [15]). The observation of digital transformation indicators shows that the companies' effort is placed in customer data and services hiring management at this moment, and there is a reasonable coverage of asynchronous contact channels, but there is also a remarkable gap in attending synchronous channels - except for the traditional contact phone- such as online chat (including human-managed chats and chatbots) and instant messaging. It is also interesting to point out the lack of mobile app development among companies; this finding points out to an opportunity for companies seeking to engage customers and encouraging energy-efficient behaviors while increasing their efficiency, for example through gamified experiences [69]. Another area of improvement is real-time consumption monitoring. Efficient consumption monitoring requires investment in integrating the information available only to distributors into the company's internal systems, but also opens the door to enhancing other digital services, such as those related to custom reporting and assessment, personalized marketing offers, or smart home device integration and management. The results also show a disparity in channel integration, which evidences a slow transition of companies from single-channel operation to multichannel and omnichannel strategies. Only six out of the nineteen companies offer their services through both physical and digital channels, and some of them only limit their physical presence to selected areas of Spain. While this limited presence may be explained, only in part, by the availability of the transport network to operate in some parts of the nation, the data reveal that, in a similar approach as that taken by Spanish virtual mobile network operators, most recently established retailers are primarily focusing on digital channels. This decision may hinder their expansion, as shown by the latest trend in retailing of expanding the boundaries of digital business to physical contexts [70,71], and pure digital players may be at risk of becoming niche players. Among multichannel companies, the same comment about the lack of integration of communication channels apply to channel integration. There is also room for improvement regarding channel consistency and integrated access to information, which may cause consumers to perceive differences in the service provided through the digital and physical channels, thus deteriorating customer experience and becoming a potential source of dissatisfaction [34].

The results of the cluster analysis confirm the gap between larger, well-established companies, and the rest of companies. This finding seems to support the idea that larger companies are better prepared for the transition to digital customer-centric strategies and omnichannel retailing, leveraged by higher access to financial resources, investment capabilities and innovation. The study finds that one of the main differences between leading companies and the rest lies in the deployment and utilization of online customer touchpoints (web portals and customer communication channels), remote consumption monitoring and complete online services hiring. The success in terms of customer and revenue growth of smaller companies that are aligned with these value proposals (e.g., Hola Luz and Mipodo) suggests that, in a digital and customer-centric paradigm, companies aspiring to remain competitive should start implementing these services.

\subsection{Limitations of the Study and Avenues of Future Research}

Due to the exploratory nature of the study, there are some limitations that should be pointed out. First, the sample consists only of Spanish companies, limiting the generalizability of results and requiring the confirmation of the findings of this study in other national contexts. Second, the analysis only covers a selected sample of companies, those operating at a nationwide scale in the free market. Future studies should also include regional companies and reference retailers (i.e., those operating in 
the regulated market) to allow for comparison of results. Third, the study limits to the consumers' view of the digital transformation and channel integration of electricity retailers. We acknowledge that the digital transformation affects all operations of the company and, in the case of electricity retailers, the deeper changes may lie not the front-end, customer-oriented activities, but rather in the incorporation of digital technologies to internal and inter-organizational processes. While such an approach exceeds the scope of this study, it would also complement and enrich the results found in this research. In addition, the results of this study could be confronted with consumers' perceptions about the service provided by each company and their actual use of the different services to better guide companies into their successful implementation. Finally, this study only focuses on the digitalization and channel integration of electricity retailers. As such, other important considerations affecting consumers' views, especially those regarding services oriented toward sustainability are not captured here. We find some of them, such as self-generation and consumption, use of renewable energies or electric vehicles, of special interest and worth exploring in future studies.

Author Contributions: Conceptualization, J.C.-P., E.A.-N., and Á.H.-G.; Methodology, J.C.-P. and E.A.-N.; Validation, E.A.-N.; Formal analysis, E.A.-N. and Á.H.-G.; Investigation, E.A.-N. and Á.H.-G.; Resources, S.I.-P.; Data curation, Á.H.-G. and S.I.-P.; Writing-original draft preparation, J.C.-P. and E.A.-N.; Writing-review and editing, Á.H.-G. and S.I.-P.; Visualization, S.I.-P.; Supervision, J.C.-P.; Project administration, J.C.-P. All authors have read and agreed to the published version of the manuscript.

Funding: This research received no external funding.

Conflicts of Interest: The authors declare no conflict of interest.

\section{Appendix A}

Figures A1-A3 summarize the result of the full analysis of digital transformation and channel integration indicators.

\begin{tabular}{l|l|l|}
\hline & \multicolumn{2}{|c|}{ Channel integration (I) } \\
\hline COMPanY & \multicolumn{2}{|c|}{ Touchpoints } \\
\hline DISA ENERGIA ELECTRICA & & \\
ENDESA ENERGIA & \\
IBERDROLA CLIENTES & \\
EDP ENERGIA \\
NEXUS ENERGIA \\
FENIE ENERGIA \\
CEPSA GAS Y ELECTRICIDAD \\
AURA ENERGIA \\
ATLAS ENERGIA COMERCIAL \\
EVERGREEN ELECTRICA \\
ALDRO ENERGIA Y SOLUCIONES \\
AB ENERGIA 19O3 \\
COX ENERGY SOLAR \\
GEO ALTERNATIVA (MIPODO) \\
SUNAIR ONE ENERGY \\
HIDROELECTRICA EL CARMEN ENERGIA \\
ENERGYA VM GESTION DE ENERGIA \\
GESTERNOVA \\
HOLALUZ-CLIDOM
\end{tabular}

Figure A1. Summary of indicators of channel integration (touchpoints). Indicator coloring scheme: green $=1$; red $=0$; and yellow $=0.5$. Company color scheme: yellow: Cluster $1 ;$ blue: Cluster 2 ; and white: mixed results. 


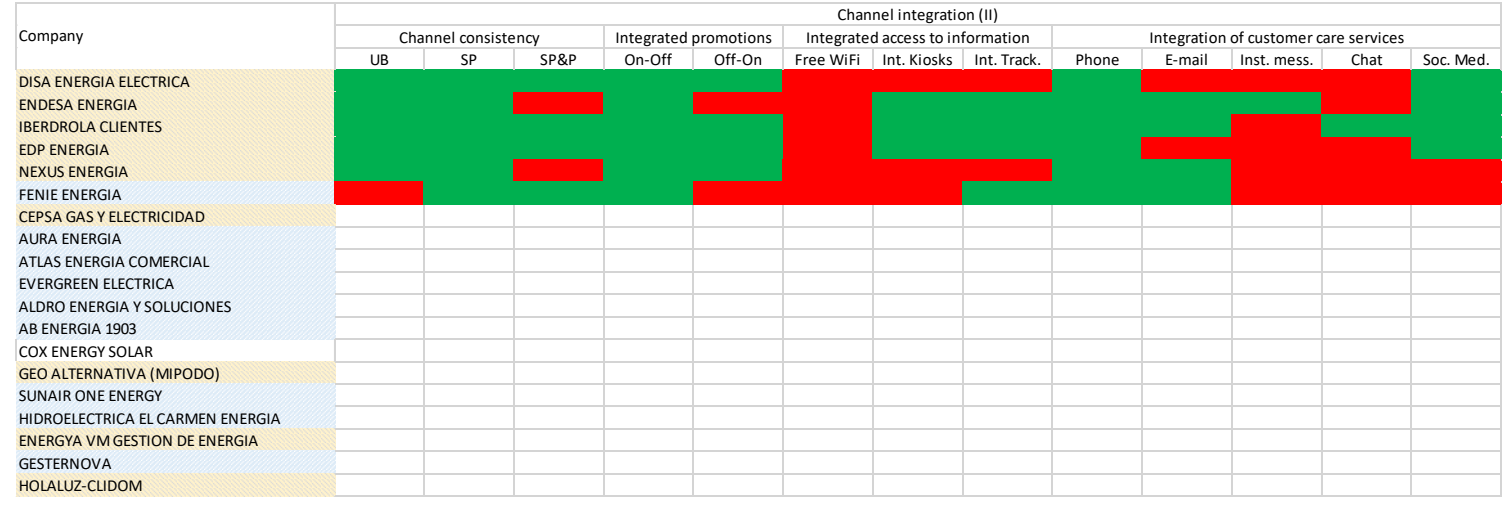

Figure A2. Summary of indicators of channel integration (II). Indicator coloring scheme: green = 1; red $=0$. Company color scheme: yellow: Cluster 1; blue: Cluster 2; white: mixed results.

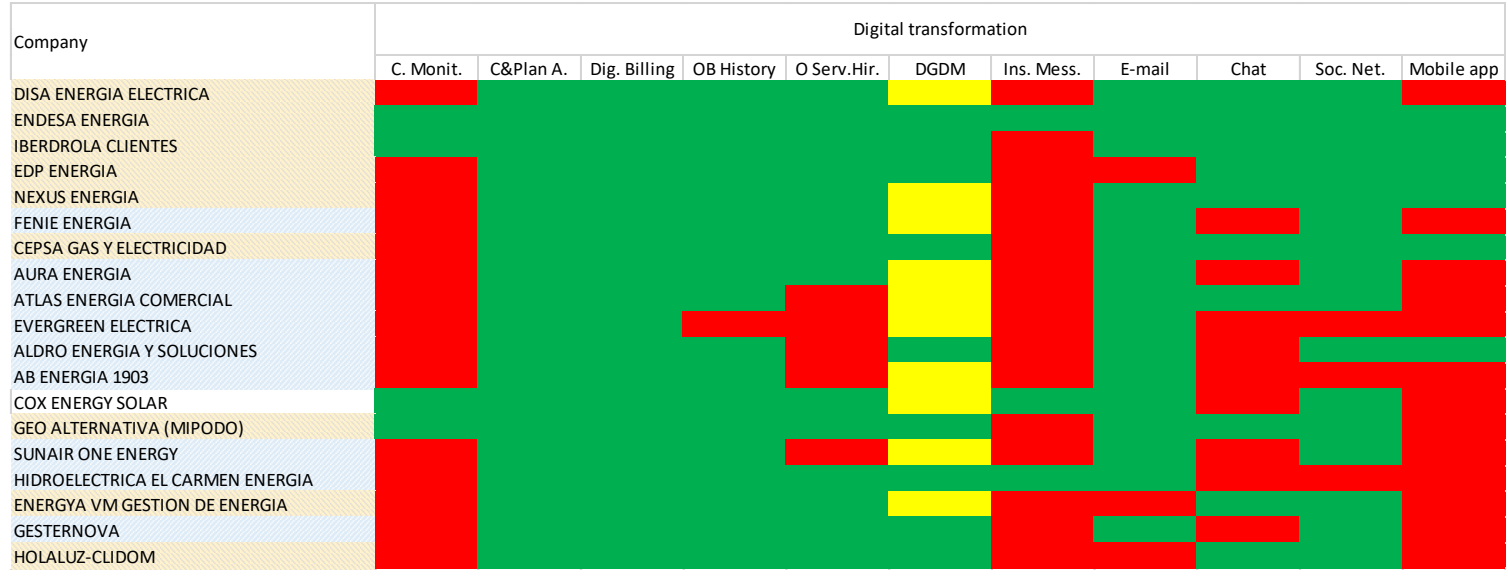

Figure A3. Summary of indicators of digital transformation. Indicator coloring scheme: green $=1$; red $=0$; yellow $=0.5$. Company color scheme: yellow: Cluster 1; blue: Cluster 2; white: mixed results.

\section{References}

1. Pollitt, M.G. The European Single Market in Electricity: An Economic Assessment. Rev. Ind. Organ. 2019, 55, 63-87. [CrossRef]

2. Pérez González, D.; Solana-González, P.; Trigueros Preciado, S. Economía del dato y transformación digital en pymes industriales: Retos y oportunidades. Econ. Ind. 2018, 409, 37-45.

3. Pelau, C.; Acatrinei, C. The Paradox of Energy Consumption Decrease in the Transition Period towards a Digital Society. Energies 2019, 12, 1-16. [CrossRef]

4. Reis, J.; Amorim, M.; Melão, N.; Matos, P. Digital Transformation: A Literature Review and Guidelines for Future Research. Adv. Intell. Syst. Comput. 2018, 745, 411-421.

5. Piotrowicz, W.; Cuthbertson, R. Introduction to the Special Issue Information Technology in Retail: Toward Omnichannel Retailing. Int. J. Electron. Commer. 2014, 18, 5-16. [CrossRef]

6. Simone, A.; Sabbadin, E. The New Paradigm of the Omnichannel Retailing: Key Drivers, New Challenges and Potential Outcomes Resulting from the Adoption of an Omnichannel Approach. Int. J. Bus. Manag. 2017, 13, 85-109. [CrossRef]

7. Frambach, R.T.; Roest, H.C.; Krishnan, T.V. The impact of consumer Internet experience on channel preference and usage intentions across the different stages of the buying process. J. Interact. Mark. 2007, 21, $26-41$. [CrossRef]

8. Blázquez, M. Fashion Shopping in Multichannel Retail: The Role of Technology in Enhancing the Customer Experience. Int. J. Electron. Commer. 2014, 18, 97-116. [CrossRef]

9. Gensler, S.; Verhoef, P.C.; Böhm, M. Understanding consumers' multichannel choices across the different stages of the buying process. Mark. Lett. 2012, 23, 987-1003. [CrossRef] 
10. Bendoly, E.; Blocher, J.D.; Bretthauer, K.M.; Krishnan, S.; Venkataramanan, M.A. Online/In-Store Integration and Customer Retention. J. Serv. Res. 2005, 7, 313-327. [CrossRef]

11. European Commission. EU Energy Markets 2014; EU: Brussels, Belgium, 2014.

12. Consejo Económico y Social España. El Sector Eléctrico En España; Consejo Económico y Social España: Madrid, Spain, 2017.

13. Consejo económico y social España. La Digitalización de la Economía; Consejo económico y social España: Madrid, Spain, 2017.

14. Roland Berger. España 4.0: El reto de la Transformación Digital de la Economía; Roland Berger: Madrid, Spain, 2016.

15. Acquila-Natale, E.; Chaparro-Peláez, J. The long road to omnichannel retailing: An assessment of channel integration levels across fashion and apparel retailers. Eur. J. Int. Manag. 2020. (In press) [CrossRef]

16. Red Eléctrica de España. El Marco Legal Estable: Economía del Sector Eléctrico Español 1988-1997; Red Eléctrica de España: Madrid, Spain, 2008.

17. Boletín Oficial del Estado. Ley 54/1997 del Sector Eléctrico (de 27 de Noviembre); Boletín Oficial del Estado: Madrid, Spain, 1997.

18. Ministerio para la Transición Ecológica y el Reto Demográfico. Estructura del Sector. Available online: https://energia.gob.es/electricidad/Paginas/sectorElectrico.aspx (accessed on 1 March 2020).

19. Energía y Sociedad. Manual de la Energía. Available online: http://www.energiaysociedad.es/manenergia/ energia-y-sociedad/ (accessed on 1 March 2020).

20. MITECO/IDEA. Energía Eléctrica: Evolución por Sectores; 2018. Available online: http://sieeweb.idae.es/ consumofinal (accessed on 27 March 2020).

21. Boletín Oficial del Estado. Ley 24/2013 del Sector Eléctrico (26 de Diciembre); Boletín Oficial del Estado: Madrid, Spain, 2013.

22. Deloitte. Situación Económico-Financiera de las Principales Empresas del Sector Eléctrico en España 2016-2018; Deloitte: Madrid, Spain, 2019.

23. Comisión Nacional de los Mercados y la Competencia. Listado de Comercializadoras de Electricidad. Available online: https://sede.cnmc.gob.es/listado/censo/2 (accessed on 15 January 2020).

24. Comisión Nacional de los Mercados y la Competencia. Informe de Supervisión del Mercado Minorista de Electricidad; Comisión Nacional de los Mercados y la Competencia: Madrid, Spain, 2019.

25. European Commission. Consumer Markets Scoreboard: Making Markets Work for Consumers; EC: Brussels, Belgium, 2018.

26. Fitzgerald, M.; Kruschwitz, N.; Bonnet, D.; Welch, M. Embracing digital technology: A new strategic imperative. MIT Sloan Manag. Rev. 2014, 55, 1-16.

27. McDonald, M.P.; Rowsell-Jones, A. The Digital Edge: Exploiting New Technology and Information for Business Advantage; Gartner Inc.: Stamford, CT, USA, 2012.

28. Yeager, K.E. Electricity for the 21st century: Digital electricity for a digital economy. Technol. Soc. 2004, 26, 209-221. [CrossRef]

29. Osmundsen, K. Competences for Digital Transformation: Insights from the Norwegian Energy Sector. In Proceedings of the 53rd Hawaii International Conference on System Sciences, Maui, HI, USA, 7-10 January 2020; Volume 3, pp. 4326-4335.

30. Glachant, J.M.; Rosetto, N. The Digital World Knocks at Electricity's Door: Six Building Blocks to Understand Why. In Florence School of Regulation; European University Institute: Florence, Italy, 2018; pp. 1-8.

31. Frazer, M.; Stiehler, B.E. Omnichannel Retailing: The Merging of the Online and Off-Line Environment. Glob. Conf. Bus. Financ. Proc. 2014, 9, 655-657.

32. Nielsen. Global Connected Commerce: Is e-Tail Therapy the New Retail Therapy? Nielsen: New York, NY, USA, 2016.

33. Verhoef, P.C.; Kannan, P.K.; Inman, J. From Multi-Channel Retailing to Omni-Channel Retailing. J. Retail. 2015, 91, 174-181. [CrossRef]

34. Brynjolfsson, E.; Hu, Y.J.; Rahman, M.S. Competing in the Age of Omnichannel Retailing. MIT Sloan Manag. Rev. 2013, 54, 23-29.

35. Cao, L.; Li, L. The Impact of Cross-Channel Integration on Retailers' Sales Growth. J. Retail. 2015, 91, $198-216$. [CrossRef] 
36. Beck, N.; Rygl, D. Categorization of multiple channel retailing in Multi-, Cross-, and Omni-Channel Retailing for retailers and retailing. J. Retail. Consum. Serv. 2015, 27, 170-178. [CrossRef]

37. Cook, G. Customer experience in the omni-channel world and the challenges and opportunities this presents. J. Direct Data Digit. Mark. Pr. 2014, 15, 262-266. [CrossRef]

38. Kemperman, A.; Van Delft, L.; Borgers, A. Omni Channel Fashion Shopping, in Successful Technological Integration for Competitive Advantage in Retail Settings; IGI Global: Hershey, PA, USA, 2015; pp. 144-167.

39. McCormick, H.; Cartwright, J.; Perry, P.; Barnes, L.; Lynch, S.; Ball, G. Fashion retailing-past, present and future. Text. Prog. 2014, 46, 227-321. [CrossRef]

40. Peltola, S.; Vainio, H.; Nieminen, M. Key Factors in Developing Omnichannel Customer Experience with Finnish Retailers. Springer Int. Publ. 2015, 9191, 335-346.

41. Seck, A.M. The issue of Multichannel Integration, a Key Challenge for Service Firms in a context Multichannel Services Distribution. Int. Bus. Res. 2013, 6, 160-167.

42. Stone, M.; Hobbs, M.; Khaleeli, M. Multichannel customer management: The benefits and challenges. J. Database Mark. Cust. Strat. Manag. 2002, 10,39-52. [CrossRef]

43. Saghiri, S.; Wilding, R.; Mena, C.; Bourlakis, M. Toward a three-dimensional framework for omni-channel. J. Bus. Res. 2017, 77, 53-67. [CrossRef]

44. Accenture. Cross Channel Integration: The Next Step for High Performing Retailers; Accenture: Dublin, Ireland, 2010.

45. Gajanan, S.; Basuroy, S. Multichannel Retailing And Its Implications On Consumer Shopping Behavior. J. Shopp. Cent. Res. 2007, 14, 1-28.

46. ATKearney. On Solid Ground: Brick-and-Mortar Is the Foundation of Omnichannel Retailing; ATKearney: Chicago, IL, USA, 2014.

47. Forrester. Customer Desires vs. Retailer Capabilities: Minding the Omni-Channel Commerce Gap; Forrester: Cambridge, MA, USA, 2014.

48. Weill, P.; Woerner, S.L. Thriving in an Increasingly Digital Ecosystem. MIT Sloan Manag. Rev. 2015, 56, $27-34$.

49. Avensia. OmniChannel Retail 2015: A Scandinavian Omni-Channel Index; Avensia: Lund, Sweden, 2015.

50. Murray, A.; Hernandez, T. The Canadian Omni-Channel Retail Landscape; Centre for the Study of Commercial Activity (CSCA): Toronto, ON, Canada, 2016.

51. National Retail Federation. Omnichannel Retail Index; National Retail Federation: Washington, DC, USA, 2015.

52. Mhe Consumer. OmniChannel Mhe Retail Index 2018; Mhe Consumer: Madrid, Spain, 2018.

53. Cao, L. Business Model Transformation in Moving to a Cross-Channel Retail Strategy: A Case Study. Int. J. Electron. Commer. 2014, 18, 69-96. [CrossRef]

54. Zhang, J.; Farris, P.W.; Irvin, J.W.; Kushwaha, T.; Steenburgh, T.J.; Weitz, B. Crafting Integrated Multichannel Retailing Strategies. J. Interact. Mark. 2010, 24, 168-180. [CrossRef]

55. Neslin, S.A.; Grewal, D.; Leghorn, R.; Shankar, V.; Teerling, M.; Thomas, J.S.; Verhoef, P.C. Challenges and Opportunities in Multichannel Customer Management. J. Serv. Res. 2006, 9, 95-112. [CrossRef]

56. Shankar, V.; Inman, J.; Mantrala, M.; Kelley, E.; Rizley, R. Innovations in Shopper Marketing: Current Insights and Future Research Issues. J. Retail. 2011, 87, S29-S42. [CrossRef]

57. Goersch, D. Multi-channel integration and its implications for retail web sites. In Proceedings of the 10th European Conference On Information Systems (ECIS), Gdańsk, Poland, 6-8 June 2002; 11, pp. 748-758.

58. Picot-Coupey, K.; Huré, E.; Piveteau, L. Channel design to enrich customers' shopping experiences. Int. J. Retail. Distrib. Manag. 2016, 44, 336-368. [CrossRef]

59. Oh, L.-B.; Teo, H.-H.; Sambamurthy, V. The effects of retail channel integration through the use of information technologies on firm performance. J. Oper. Manag. 2012, 30, 368-381. [CrossRef]

60. Avery, J.; Steenburgh, T.J.; Deighton, J.; Caravella, M. Adding Bricks to Clicks: Predicting the Patterns of Cross-Channel Elasticities over Time. J. Mark. 2012, 76, 96-111. [CrossRef]

61. Schramm-Klein, H.; Wagner, G.; Steinmann, S.; Morschett, D. Cross-channel integration-Is it valued by customers? Int. Rev. Retail. Distrib. Consum. Res. 2011, 21, 501-511. [CrossRef]

62. Black, N.J.; Lockett, A.; Ennew, C.; Winklhofer, H.; McKechnie, S. Modelling consumer choice of distribution channels: An illustration from financial services. Int. J. Bank Mark. 2002, 20, 161-173. [CrossRef]

63. Park, J.; Stoel, L. Effe, ct of brand familiarity, experience and information on online apparel purchase. Int. J. Retail. Distrib. Manag. 2005, 33, 148-160. [CrossRef] 
64. Herhausen, D.; Binder, J.; Schoegel, M.; Herrmann, A. Integrating Bricks with Clicks: Retailer-Level and Channel-Level Outcomes of Online-Offline Channel Integration. J. Retail. 2015, 91, 309-325. [CrossRef]

65. Deloitte. Global Powers of Retailing 2015: Embracing Innovation; Deloitte: London, UK, 2015.

66. Wu, I.-L.; Wu, S.-M. A strategy-based model for implementing channel integration in e-commerce. Internet Res. 2015, 25, 239-261. [CrossRef]

67. Wilson, A. The Use of Mystery Shopping in the Measurement of Service Delivery. Serv. Ind. J. 1998, 18, 148-163. [CrossRef]

68. PwC. The Digital Transformation of Small and Medium-Sized Enterprises. Available online: https: //www.pwc.nl/en/topics/economic-office/europe-monitor/the-digital-transformation-of-smes.html (accessed on 2 April 2020).

69. Beck, A.L.; Chitalia, S.; Rai, V. Not so gameful: A critical review of gamification in mobile energy applications. Energy Res. Soc. Sci. 2019, 51, 32-39. [CrossRef]

70. Huré, E.; Picot-Coupey, K.; Ackermann, C.-L. Understanding omni-channel shopping value: A mixed-method study. J. Retail. Consum. Serv. 2017, 39, 314-330. [CrossRef]

71. Grewal, D.; Roggeveen, A.L.; Nordfält, J. The Future of Retailing. J. Retail. 2017, 93, 1-6. [CrossRef]

(C) 2020 by the authors. Licensee MDPI, Basel, Switzerland. This article is an open access article distributed under the terms and conditions of the Creative Commons Attribution (CC BY) license (http://creativecommons.org/licenses/by/4.0/). 